\title{
Study of Green Seaweed Biochar for Lead Adsorption from Aqueous Solution
}

\author{
KARISHMA D. SHAH ${ }^{1}$, NAYANA H. BRAHMBHATT ${ }^{1 *}$ and POOJA N. THAKER ${ }^{1}$ \\ Department of Biology, V. P \& R. P. T. P Science College, Sardar Patel University, \\ Vallabh Vidhyanagar-388120, Gujarat, India. \\ *Corresponding author E-mail: naina_bbhatt@yahoo.co.in \\ http://dx.doi.org/10.13005/ojc/370532
}

(Received: September 25, 2021; Accepted: October 27, 2021)

\begin{abstract}
The current work used a batch study to investigate the efficiency of Ulva lactuca carbon for lead adsorption from aqueous solution. For the optimization study, the effects of several parameters such as $\mathrm{pH}$, Adsorbent dosage, effective contact time, and initial concentration on lead removal were also considered. $\mathrm{pH} 3$ was observed to be the most beneficial. The Langmuir isotherm, which represents mono-layer adsorption, yielded a maximum lead absorption of $3.49 \mathrm{mg} / \mathrm{g}$. SEM was used to examine surface adsorption behavior, and FTIR was used to detect probable functional groups involved in the bio-adsorption experiment. This study shows that biochar made from the marine algae Ulva lactuca is effective for waste water treatment.
\end{abstract}

Keywords: Heavy metal, Lead, Adsorption, Bio-removal, Waste water treatment, Biochar.

\section{INTRODUCTION}

With growing development, pollution levels are rising, disrupting the ecological balance and posing a health risk if not effectively handled. Acid, alkalis, anions (sulphides, sulphites, and cyanide), detergents, sewage, nutrient, and metal, toxic waste, pesticide, radionuclide, and various organic compounds are released as a pollutant. ${ }^{1}$ Safe and sufficient quantity is a basic requirement of humans. The interval between water demand and fresh water availability is rising day by day. There is an urgent need to develop methods that can keep the pollution in check and protect our environment while being economical at the same time. ${ }^{2}$
Heavy metals and other hazardous chemicals, generated from natural or industrial sources, act as serious threats to mankind ${ }^{3}$. Among various heavy metals, lead is a particularly toxic metal even at the lowest exposure. The production and consumption of lead ore, metal compounds, and lead containing products are worldwide phenomena. Lead is widely used in battery manufacturing. Global consumption of lead is increasing day by day. Lead is causing cardiovascular diseases, development abnormalities, neurologic and neurobehavioral disorders. Lead is also considered teratogenic. Lead especially affects the blood, central nervous system, kidneys, reproductive system and immune system. Lead is toxic to flora, fauna and microbes. Despite the dramatic worldwide production, consumption

This is an Open Access article licensed under a Creative Commons license: Attribution 4.0 International (CC- BY). Published by Oriental Scientific Publishing Company @ 2018

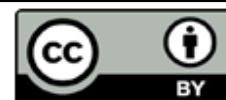


and release of lead compounds in the environment, there is no efficient way for recycling ${ }^{4}$.

Conventional treatments like ion exchange, chemical precipitation, membrane filtration, coagulation flocculation are not economical. Removal and recovery of heavy metal from the effluent is necessary for environmental concerns. The introduction of efficient and cost-effective technology for the environment friendly treatment of industrial wastewater can help to achieve a cleaner and more sustainable development ${ }^{5}$. Amongst all effluent treatments activated carbon (AC) is the most widely used adsorbent material for the separation of contaminants from wastewater because of its broad adaptability ${ }^{6}$. The main downside of the utilization of activated carbon is its higher cost of synthesis and regeneration ${ }^{7}$. Because of its lower synthesis cost than activated carbon, biochar is now being potential alternative ${ }^{8}$. This study focused on low cost biochar for lead removal from aqueous solution.

\section{MATERIAL AND METHOD}

\section{Algal collection and biomass preparation}

Fresh green algae species Ulva lactuca was collected from the Okha coast, Dwarka district, Gujarat. To eliminate dirt and other pollutants, it was cleaned with tap water. It was sun-dried for 24 hours. The alga was then placed in a $60^{\circ} \mathrm{C}$ oven for $2 \mathrm{~h}$ to remove any leftover moisture. After drying the algae, it was shredded, crushed and sieved to obtained uniform size particles $(0.71 \mathrm{~mm})$ and kept in a muffle furnace at $450^{\circ} \mathrm{C}$ temperature for $20 \mathrm{~min}$ in order to convert it into carbon.

\section{Preparation of standard metal solution}

The standard solution of $1000 \mathrm{mg} / \mathrm{L}$ Merck Certified Reference Material (CRM) of lead solution was used. All chemicals used were A.R grade.

\section{Batch Adsorption experiment}

The batch study of lead biosorption began with an optimal $\mathrm{pH}$ study for $60 \mathrm{~min}$ on constant agitation time. The sample was filtered using Grade A Whatman filter paper after $60 \mathrm{~min}$ and the initial and final concentrations of aqueous solutions were measured using an Air acetylene Thermo Fisher Scientific SA13020291 Atomic Adsorption Spectrophotometer (A.A.S). After achieving the optimal $\mathrm{pH}$, various biosorption characteristics such as effective dose, duration, and optimal concentration were investigated. During each experiment, one parameter is changed while the others remain fixed in order to get the best possible environmental circumstances.

\section{Effect of pH on Biosorption}

A series of flasks containing 3 to $7 \mathrm{pH}$ of $100 \mathrm{~mL}$ lead solution, $0.5 \mathrm{~g}$ adsorbent dosage, $120 \mathrm{RPM}, 5 \mathrm{mg} / \mathrm{L}$ concentration for $60 \mathrm{~min}$ were used to evaluate the optimum $\mathrm{pH}$ for biosorption. The $\mathrm{pH}$ of the aqueous solutions was adjusted by $0.2 \mathrm{M} \mathrm{H}_{2} \mathrm{SO}_{4}$ and $0.1 \mathrm{M} \mathrm{NaOH}$ during an experiment. The $\mathrm{pH}$ is significant factor for adsorption because it affects the surface charge of the adsorbent and the degree of ionization in the experiment ${ }^{10}$. It is observed that heavy metal biosorption is generally effective at lower $\mathrm{pH}$ because binding site may not activate in basic conditions ${ }^{9}$. In our biosorption analysis, we found $\mathrm{pH} 3$ to be the optimum $\mathrm{pH}$, as shown in Fig. 1. Dursun discovered that $\mathrm{pH}$ of the solution affects both metal binding sites on the cell surface and the chemistry of metal in solution as more surfaces are available for treatment. ${ }^{10}$ The ideal $\mathrm{pH}$ was determined by a flask with a better lead removal rate.

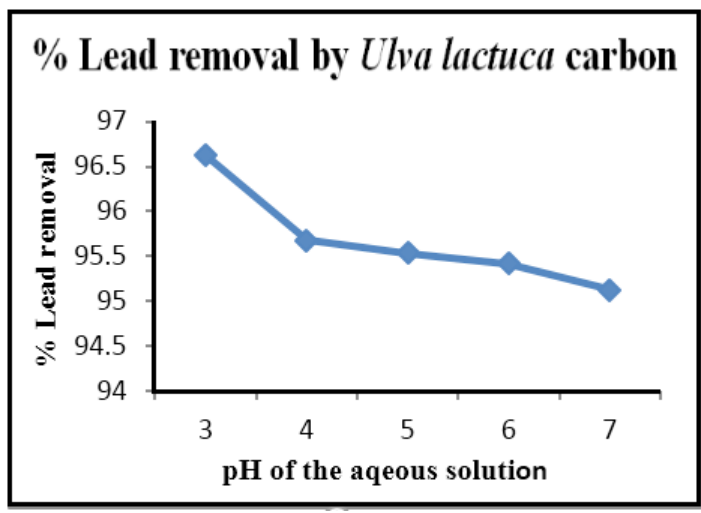

Fig. 1. Effect of pH on biosorption

\section{Effect of Adsorbent dose on bio-adsorption}

Various doses of seaweed carbon were taken in conical flaks containing $100 \mathrm{~mL}$ lead solution, $\mathrm{pH} 3$ (obtained by $\mathrm{pH}$ optimization), 120 RPM speed, and 60 min contact period to determine the effective dose of carbon. The difference in before and after adsorption treatment outcomes is used to estimate the optimal duration. A flask with more adsorption phenomenon is thought to be the ideal adsorbent dose for removing lead. The effect of 
biomass dose on lead is shown in Fig. 2. Due to the increasing availability of adsorbent, the metal uptake rate rose as the carbon dosage was raised. The curve's initial tendency was upward, which could be attributed to the large number of unoccupied active sites in the adsorbent. This curve shifted gradually by the end, which can be attributed to the saturation of the adsorbent's active sites. Sari Ahmet et al., and Alyuz Bilge et al., achieved a similar graphical trend in their experimental work. ${ }^{11,12}$

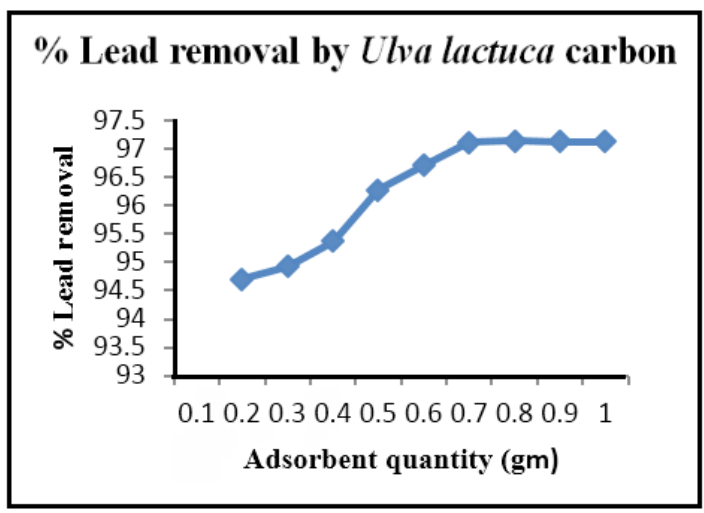

Fig. 2. Effect of adsorbent dose on biosorption

\section{\% Lead removal by Ulva lactuca carbon}

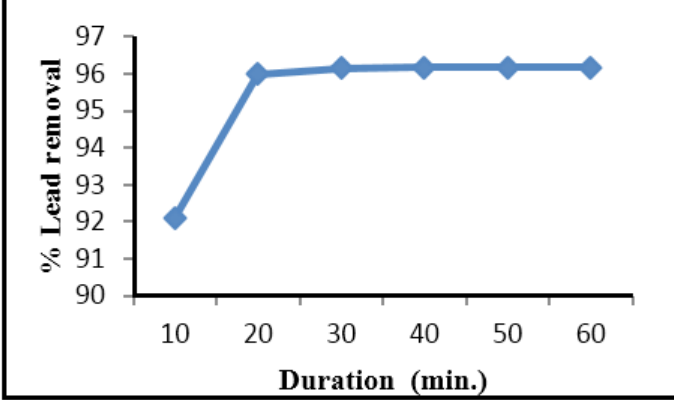

Fig. 3. Effect of Contact time on biosorption

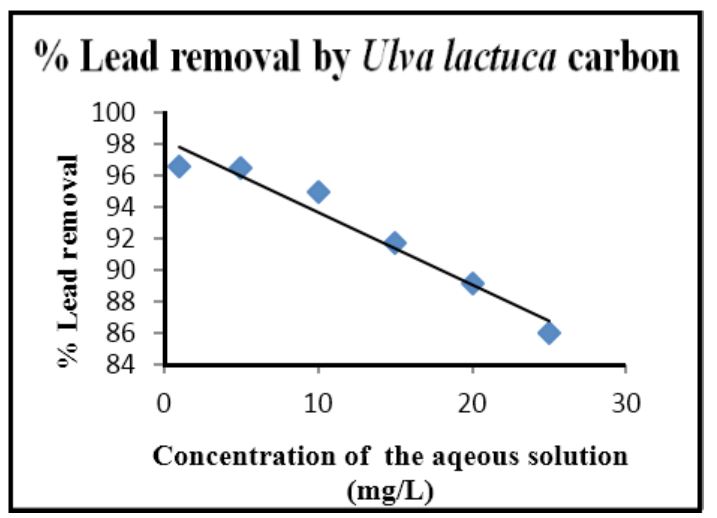

Fig. 4. Effect of Concentration on biosorption

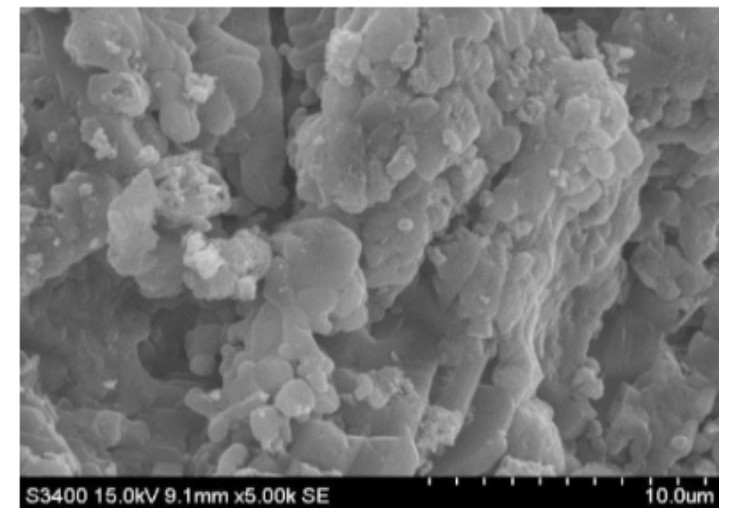

Fig. 5. Ulva lactuca carbon untreated

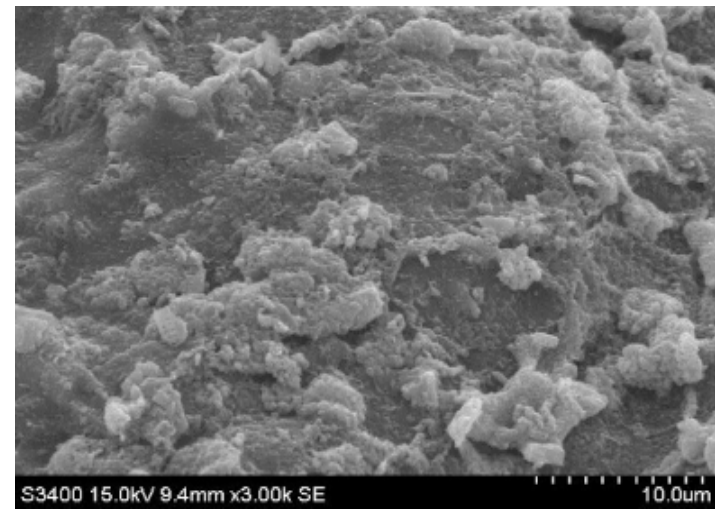

Fig. 6. SEM image of Ulva lactuca carbon after lead adsorption Effect of Contact Time on bio-adsorption

The effect of contact time for biosorption was studied for one hour on 10 min interval basis by keeping other parameters as a constant $(\mathrm{pH} 3$, $0.8 \mathrm{gm}$ adsorbent obtained from optimization study). The data obtained from the biosorption of lead on U/va lactuca carbon showed that the optimum contact time is 30 minute. It was sufficient to achieve equilibrium after that biosorption of lead did not change.

\section{Effect of Concentration on bio-adsorption}

The effect of various concentrations of the lead solution was studied within a $1-25 \mathrm{mg} / \mathrm{L}$ range. $\mathrm{pH} 3$, adsorbent dose $0.8 \mathrm{~g} / 100 \mathrm{~mL}$ taken for $30 \mathrm{~min}$ in an orbital shaker at 120 RPM. In the experimental study, the lead uptake gradually decreased with an increase in concentration. This phenomenon occurs due to the saturation of adsorbent sites available in the adsorbent. Maximum adsorption occurs at $\mathrm{pH} 3$ for $5 \mathrm{mg} / \mathrm{L}$ concentration.

\section{Scanning Electron Microscope (SEM)}

Scanning Electron Microscope (SEM) is used to determine surface phenomena before and after treatment of adsorbent. 
The results of the SEM investigation revealed considerable morphological changes in the carbon structure before and after lead adsorption. Before adsorption, the surface of the carbon picture was more porous. After adsorption, the SEM picture revealed a substantial layer of lead deposition and pore wall thickness.

\section{Fourier Transmission Infrared Spectrophotometer}

FTIR method is used to detect frequency change in adsorbent before and after treatment with lead. FTIR spectra for treated and untreated samples of carbon were recorded by $\mathrm{KBr}$ pellets method operated on FTIR spectrophotometer. For transformation of absorbance into transmittance percentage data processing was performed.

The presence of $\mathrm{C}-\mathrm{O}, \mathrm{O}-\mathrm{H}$, and other functional groups in Ulva lactuca carbon responsible for lead adsorption was demonstrated by FTIR analysis. After lead adsorption, the peaks in wave numbers 935.6, 1640 and 3242.8 disappeared indicating an interaction between Ulva lactuca carbon and lead (Graph 1\& 2). Due to lead, there was also a vibration shift in the U/va lactuca carbon peak before and after adsorption (726.8 to 674.6 , 1080.9 to $1095.8,1640$ to $1558,3485.1$ to 2333.8 ). (Table 1). Metal chelation was corroborated by these overall alterations in wave number. Due to stretching vibrations, the adsorption peak detected in untreated Ulva lactuca carbon 3485.1 and 3563.3 proved that the material is carbon. ${ }^{13}$

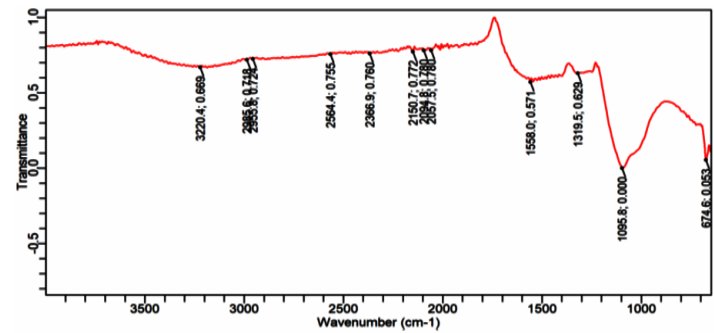

Graph. 1. FTIR Graph before lead adsorption

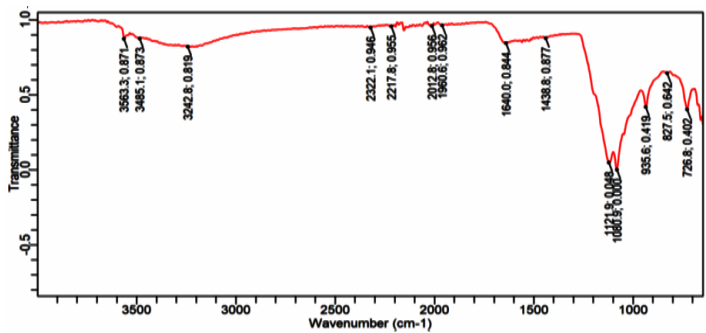

Graph. 2. FTIR Graph after lead adsorption

Table 1: FTIR Peak table

\begin{tabular}{|c|c|c|c|c|c|c|c|}
\hline Sr. No & $\begin{array}{l}\text { Standard Adsorption } \\
\text { frequency }\end{array}$ & $\begin{array}{l}\text { Functional } \\
\text { group }\end{array}$ & Compound & $\begin{array}{c}\text { Blank Ulva lactuca } \\
\text { carbon }\end{array}$ & $\begin{array}{l}\text { Functional } \\
\text { group }\end{array}$ & $\begin{array}{l}\text { Ulva lactuca } \\
\text { treated with lead }\end{array}$ & $\begin{array}{l}\text { Functional } \\
\text { group }\end{array}$ \\
\hline 1 & $480-410$ & S-S & Disulphide & $726.8,827.5$ & $\mathrm{C}-\mathrm{Cl}$ & 674.6 & $\mathrm{C}-\mathrm{Cl}$ \\
\hline 2 & 600 & $C-S, C=S$ & Sulfate & 935.6 & $\mathrm{O}-\mathrm{H}$ & - & - \\
\hline \multirow[t]{4}{*}{3} & $\begin{array}{l}\text { 1084.1-1038.1, } \\
1015\end{array}$ & $\begin{array}{l}\mathrm{C}-\mathrm{F}, \mathrm{Si}-\mathrm{O} \\
\mathrm{S}=\mathrm{O}, \mathrm{C}-\mathrm{O}\end{array}$ & Cellulose & & & & \\
\hline & & & carbohydrates & & & & \\
\hline & & & Sulfonides \& & & & & \\
\hline & & Glucose & $1080.9,1121.9$ & $\mathrm{C}-\mathrm{O}$ & 1095.8 & C-F & \\
\hline \multirow[t]{2}{*}{4} & 1244,1228 & $\mathrm{P}-\mathrm{O}$ & Phosphine/ & & & & \\
\hline & & & Phosphate & - & - & - & - \\
\hline 5 & $\begin{array}{l}1405,1400- \\
1200,1415\end{array}$ & $\begin{array}{l}\mathrm{C}-\mathrm{O}, \mathrm{O}-\mathrm{H}, \\
\mathrm{CH}_{3}-\mathrm{N}\end{array}$ & Cutin & - & - & - & - \\
\hline 6 & 1560 & $\mathrm{C}=\mathrm{C}, \mathrm{C}-\mathrm{O}$ & Lignin & - & - & 1558.0 & $\begin{array}{l}\mathrm{N}-\mathrm{H} \text { bending } \\
\text { vibration }\end{array}$ \\
\hline 7 & $\begin{array}{l}1653,1660 \\
-1655\end{array}$ & $\mathrm{C}=\mathrm{O}, \mathrm{C}-\mathrm{N}, \mathrm{N}-\mathrm{H}$ & Ester Pectin & 1640 & $\mathrm{C}=\mathrm{C}$ alkene & - & - \\
\hline 8 & 2360 & $\mathrm{C}-\mathrm{O}, \mathrm{P}+\mathrm{H}$ & Phosphine & - & - & 2150.7 & $C \equiv C$ \\
\hline 9 & $2960-2850$ & $\mathrm{~N}-\mathrm{H}, \mathrm{CH}_{3} \& \mathrm{CH}_{2}$ & $\begin{array}{l}\text { Aliphatic } \\
\text { compound }\end{array}$ & 3242.8 & $\mathrm{~N}-\mathrm{H}$ & - & - \\
\hline 10 & 3300 & $\mathrm{NH}, \mathrm{O}-\mathrm{H}$ & $\begin{array}{c}\text { Polysaccharide, } \\
\text { Aminoacids }\end{array}$ & $3485.1,3563.3$ & $\mathrm{O}-\mathrm{H}$ & 2933.8 & $-\mathrm{C}-\mathrm{H}$ strech \\
\hline
\end{tabular}

\section{Adsorption Isotherm}

Adsorption isotherm is the study of the quantity of adsorbed heavy metal. This model is used for development of equations for designing purpose. Adsorption capacity $(\mathrm{mg} / \mathrm{g})$ was studied using the below equation. ${ }^{14}$

Adsorption capacity $=\left(C_{0}-C_{e}\right)^{*} V / m$ 
Where $\mathrm{C}_{0}$ is the intial concentration of lead standard $\mathrm{C}_{e}$ is final concentration of lead standard after adsorption

$\mathrm{V}$ is the volume of sample taken

$M$ is mass of adsorbent taken

Adsorption of lead by Ulva lactuca is studied by below two models.
(1) Langmuir isotherm
(2) Freundlich isotherm

\section{Langmuir isotherm}

Langmuir isotherm is below:

$$
C_{e} / q_{e}=\left(1 / q_{o} b\right)+\left(c_{e} / q_{o}\right)
$$

Langmuir isotherm can be obtained by plotting a graph of $1 / \mathrm{C}_{\mathrm{e}}$ against $1 / \mathrm{q}_{\mathrm{e}}$. Slope and the intercept can be calculated using this graph. Langmuir constant $b$ is calculated using this method.

\section{Freundlich Isotherm}

German physical chemist Herbert Max Finley Freundlich has represented this isotherm in 1909. This model gives an idea for sorption on the heterogeneous surface. following equation.

Freundlich Isotherm is expressed by the

$$
\log q_{e}=\log K_{f}+1 / n \log C_{e}
$$

This value is obtained by plotting log $C$ versus $\log q_{e} \cdot K_{f}$ and $n$ in graph obtained by intercept and slope of graph respectively.

Comparison of Langmuir and Freundlich model for adsorption are listed in Table 2
Table 2: Comparison of Langmuir and Freundlich model for adsorption are listed in table 2

\begin{tabular}{cccccccc}
\hline Sr. No & \multicolumn{3}{c}{ Langmuir } & \multicolumn{4}{c}{ Freundlich } \\
& $\mathrm{Q}_{\max }$ & $\mathrm{b}$ & $\mathrm{R}_{2}$ & $\mathrm{~N}$ & $\mathrm{~K}_{\mathrm{F}}$ & $\mathrm{R}_{2}$ \\
\hline 1 & 3.4965 & 1.05926 & 0.999 & 0.653 & 1.44 & 0.962 \\
\hline
\end{tabular}

From the above results, Langmuir isotherm appears more suitable than Freundlich isotherm. It shows mono-layer adsorption rather than multi-layer adsorption. In Freundlich isotherm, $n$ value is less than one representing adsorption to be a chemical process.

\section{Desorption and reusability}

Desorption of heavy metal from seaweed carbon by $0.1 \mathrm{M} \mathrm{HNO}_{3}$ was studied for its reusability purpose. After eluting with $0.1 \mathrm{M} \mathrm{HNO}_{3}$, desorbing aqueous solution was measured using Atomic adsorption spectrophotometer. Effeciency of desorption can be measured as below.

Desorption recovery $=C_{1} / C_{2}{ }^{*} 100$

Where $\mathrm{C}_{2}$ is the concentration of the adsorbate on the surface of adsorbent and $C_{1}$ is the concentration of adsorbates in the solution after desorption process.

Ulva lactuca carbon recovery $=4.0777 / 4.5800 * 100$

Lead desorption by Ulva lactuca carbon achieved $89 \%$ recovery.

\begin{tabular}{|c|c|c|c|c|c|}
\hline Sr. No & Seaweed species & Solution medium & Removal rate & Optimum conditions & Reference \\
\hline 1 & $\begin{array}{l}\text { Ulva lactuca carbon } \\
\text { treated with } \mathrm{KOH} \text { in } \\
3: 1 \text { ratio }\end{array}$ & Aqeous solution & $83.34 \mathrm{mg} / \mathrm{g}$ & $\begin{array}{l}\mathrm{pH} 5 \text {, Contact time } 60 \mathrm{~min}, \\
\text { adsorbent dose } 0.8 \mathrm{~g} / \mathrm{L} \text {, } \\
\text { Concentration } 60 \mathrm{mg} / \mathrm{L}\end{array}$ & (15) \\
\hline 2 & $\begin{array}{l}\text { Ulva fasciata species } \\
\text { treated with calcium chloride } \\
\text { (CCUC), sodium carbonate (SCUC), } \\
\text { sodium sulphate treated (SSUC) }\end{array}$ & Aqeous solution & $\begin{array}{l}22.93 \mathrm{mg} / \mathrm{g} \\
24.15 \mathrm{mg} / \mathrm{g} \\
23.47 \mathrm{mg} / \mathrm{g}\end{array}$ & $\begin{array}{l}\mathrm{pH} 4 \text {, contact time } 60 \mathrm{~min} \text {, } \\
\text { adsorbent dose } 0.15 \mathrm{~g} / 100 \mathrm{~mL} \text {, } \\
\text { Concentration } 10 \mathrm{mg} / \mathrm{L}\end{array}$ & $(16)$ \\
\hline 3 & Gracilaria changii Activated carbon & Aqeous solution & $0.1 \mathrm{mg} / \mathrm{g}$ & $\mathrm{pH} 6$, contact time $30 \mathrm{~min}$, & $(17)$ \\
\hline
\end{tabular}

Table 3: Literature review of Lead removal by seaweed carbon:

\section{CONCLUSION}

Biosorption of lead using Ulva lactuca carbon has been studied in this research. The results of these experiments strongly suggested that Ulva lactuca carbon is cost-effective and capable of removing lead from aqueous solutions. Carbon can be reused by removing lead after being treated with $0.1 \mathrm{M} \mathrm{HNO}_{3}$. We can conclude from a comparison of literature review data that seaweed 
carbon is more efficient when activated than when untreated.

\section{ACKNOWLEDGMENT}

The Authors would like to express their of interest. gratitude to V.P.\& R.P.T.P. Science College, Vallabh Vidyanagar, 388120. Dist. Anand, Gujarat.

\section{Conflict of interest}

The authors declare that there is no conflict

\section{REFERENCES}

1. Fei, Li.; Heavy Metal in Urban Soil: Health RiskAssessment and Management, Chapter., 2018, 19, 337-357.

2. Ghaitidak, D.; Yadav, K., Characteristics and treatment of greywater-A review Environmental Science and Pollution Research, Environmental Science and Pollution Research., 2013, 20(5), 2795-2809.

3. Rahimzadeh M. R.; Moghadamnia, A. A., Arsenic compounds toxicity., Journal of Babol University Med Sci., 2013, 15, 51-68.

4. UNEP chemicals, Interim review of scientific information on lead, 2006, 81.

5. Tunçsiper, B. J. Clean. Prod., Interim review of scientific information on lead., 2019, 228, 1368-1376

6. Gaurav G.K.; Mehmood T.; Cheng L.; Klemeš J.J.; Shrivastava D.K., Water hyacinth as a biomass: a review, J. Clean. Prod., 2020, 277, 122-214.

7. Li, C.; Zhu, X.; He, H.; Fang, Y.; Dong H.; Lü $\mathrm{J}$.; Li, J.; Li, Y., Adsorption of two antibiotics on biochar prepared in air-containing atmosphere: influence of biochar porosity and molecular size of antibiotics, Journal of Molecular Liquids., 2019, 274, 353-361.

8. Ahmady-Asbchin, S.; Andrès, Y.; Gérente, C.; Cloirec L. P., Biosorption of $\mathrm{Cu}(\mathrm{II})$ from aqueous solution by Fucus serratus: surface characterization and sorption mechanisms, Bioresour.Technol., 2008, 99(14), 6150-6155.

9. Memon, J. R.; Memon S. Q; Bhanger, M. I.; Khuhawar, M. Y., Banana Peel: A Green and Economical Sorbent for $\mathrm{Cr}$ (III) Removal, Pakistan Journal of Analytical \& Environmental Chemistry., 2008, 9(1), 20-25.

10. Dursun, A.Y., A Comparative Study on Determination of the Equilibrium, Kinetic and
Thermodynamic Parameters of Biosorption of Copper(II) and Lead(II) lons onto Pretreated Aspergillus niger, Biochemical Engineering Journal., 2006, 28, 187-195.

11. Sari, A.; Tuzen, M., Kinetic and equilibrium studies of biosorption of $\mathrm{Pb}$ (II) and $\mathrm{Cd}$ (II) from aqueous solution by macrofungus (Amanita rubescens) biomass, Hazard Mater., 2009, 164(2-3), 1004-1011.

12. Alyuz, B.; Veli S., Kinetics and equilibrium studies for the removal of nickel and zinc from aqueous solutions by ion exchange resins, $J$ Hazard Mater., 2009, 15, 167(1-3),482-488.

13. Souza, L. D.; Devi, P.; Shridhar D.; M.P.; and Naik C. G., Use of Fourier Transform Infrared (FTIR) Spectroscopy to Study CadmiumInduced Changes in Padina Tetrastromatica (Hauck), Analytical Chemistry Insights., 2008, 3, 135-143.

14. Hamzaoui, M.; Bestani, B.; Benderdouche, The use of linear and nonlinear methods for adsorption isotherm optimization of basic green 4-dye onto sawdust-based activated carbon, $\mathrm{N}$. J. Mater. Environ. Sci., 2018, 9(4), 1110-1118.

15. Ibrahim, M. W.; Hassan, A. F.; Azab A. Y., Biosorption of toxic heavy metals from aqueous solution by Ulva lactuca activated carbon, Egyptian Journal of Basic and Applied Sciences., 2016, 3, 241-249.

16. R. P. S. J.; Chandrasekaran V., Adsorption of lead (II) ions by activated carbons prepared from marine green algae: equilibrium and kinetics studies, Int $J$ Ind Chem., 2014, 5, 1-10.

17. Isam, M.; Baloo, L; Sapari, N.; Nordin, I.; Yavari, S.; Al-Madhoun, W., Removal of Lead using Activated Carbon Derived from Red Algae (Gracilaria Changii), MATEC Web of Conferences., 2018, 203, 03006. 